\section{MOVEMENTS OF POPULATION IN THE BRITISH COMMONWEALTH}

$\mathrm{A}$

T the Brighton meeting of the British Associa. tion, a symposium was arranged by Section $\mathrm{E}$ (Geography) on population movements in the British Commonwealth. Prof. C. B. Fawcett contributed a paper on the geographical aspects of the subject; Prof. Brinley Thomas (Section F : Economics) dealt with it from the point of view of an economist ; and Mr. R. R. Rawson analysed the particular problem of White settlement on inter-tropical highlands, with special reference to Kenya and Rhodesia.

Prof. Fawcett introduced his analysis with the main facts about the distribution of population in the Commonwealth. He described it as the least densely peopled of the major political units of the world. More than half the total area consists of the arctic or sub-arctic regions of Canada, or the arid and semi-arid zones of Australia and South Africa. The Dominions, the total area of which covers about one-seventh of all the inhabited land, contain not more than one-fifteenth of the good agricultural land of the world. England, with its 40 million people on 50,000 square miles of land, that is to say, about 800 persons a square mile, is the most densely settled country in the world. The striking unevenness of the distribution of the population of the Commonwealth raises the question whether the younger Dominions are under-peopled.

In considering this very topical problem, Prof. Fawcett saw reason to approve measures such as the 'White Australia' policy. He stressed that any 'foreign' minorities which remain distinct communities in the population tend to lessen its social and political unity, and that the acute colour problems in South Africa and the United States are an objectlesson which justify Australians in their determ. ination to keep out races difficult to assimilate. Prof. Fawcett doubted whether the economic effects of immigration are the most significant ones. To quote his words, "the colour problems of the United States and the communal differences of India are sufficient evidence that the world has not yet reached the level of civilization in which a plural society, with wide cultural or racial difference between its component communities, can form a satisfactory social or political unit of free people".

Prof. Fawcett cited with approval the following estimates of the probable populations which the Dominions could support at the present standards of living: Australia, 30-50 million; Canada, 60-100 million. In Australia the increase could be brought about in three ways : by closer rural settlement in the well-watered areas, expansion of tropical agriculture in the east coastal areas of Queensland, and industrial development based on mineral resources, especially coal. Britain could not be expected to supply agricultural migrants, in view of the drive to grow more food at home. Similarly, while full employment continues, there would be little chance of a large-scale transfer of industrial workers. After referring to the effect of social security and the demographic consequences of the pre-war fall in the birth-rate, Prof. Faweett concluded that any con. siderable migration would accentuate the change in the balance between the lower and upper age-groups.

The next paper, "The Economies of Commonwealth Migration", was read by the present writer. The argument may be summarized as follows. Despite all the efforts made to people the Dominions with migrants from Britain, there was a net overflow of population from the British Empire to the rest of the world amounting to 5.9 million in the years 1836-1900 and 250,000 in the period 1901-36. Of the ten million British people who crossed the seas in the half-century 1845-1894, 68 per cent went to the United States, 16 per cent to Australia and New Zealand, and 12 per cent to Canada.

What were the main determinants of these migration movements? First, there was a sharp difference between the relative quantities of factors of production in the Old World and in new countries; the marginal productivity of labour overseas was much higher than it was in Europe. Secondly, capital exports tended to be accompanied by migration of labour. The last great burst of emigration from Britain coincided with the absorption of a considerable volume of capital by Canada, when the Prairie Provinces were being opened up in the early years of this century. Thirdly, the direction of the flow of British emigrants was strongly influenced by the contrast between the high degree of equality of opportunity in the United States and the class barriers in Great Britain. Under the influence of the ideas of Edward Gibbon Wakefield, British colonization policy was designed to reproduce in the oversea dependencies the social structure of the homeland. It met with little success because the facts in the Colonies were too strong for it. It was the discovery of gold, not the colonization theories of Whitehall, which gave a real impetus to the growth of Australia.

The inter-war period was dominated by the drastic immigration restrictions introduced by the United States in 1924. The consequences were far-reaching. Agricultural protectionism was stimulated in Europe, and capital from the United States was encouraged to flow to the Old World, since population was prevented from migrating to America. In these new circumstances the Empire settlement policy launched by the British Government led to disappointing results. The net amount of British emigration to the Empire fell from 113,000 in 1922 to 63,000 in 1929 ; and during the thirties the stream actually turned the other way, Britain receiving an inward balance of 126,000 migrants from the Dominions.

A cardinal weakness of the ideas underlying this policy of peopling the Empire was the failure to realize that Britain was no longer able to export capital on the appropriate scale. Moreover, a significant change was taking place in the economic relationship between agricultural and industrial countries. As the Western world became richer, a greater proportion of income was being devoted to amenities, and a smaller proportion to necessities; hence the growth of employment in personal services, distribution, entertainment, etc. Despite this trend, Empire migration policy continued to be based on extensive land settlement in the Dominions. This objective was not consistent with the new direction which was being given to the productive forces of the Western world by the rising level of affluence.

Against this background, the paper proceeded to an analysis of the bearing of migration on the current economic crisis, the hypothesis of a planned transfer of population for strategic reasons being left out of account. Large-scale emigration would weaken the lower age-groups which contain the most productive labour. It would be accompanied by an export of capital which would accentuate Great Britain's difficulties. In 1947 , a year of severe crisis in the 
balance of payments, no less than a third of the toll on British reserves was caused by export of capital, a good proportion of which consisted of emigrants' funds and money invested in Dominion securities. Moreover, by accentuating the scarcity of manpower in industries where the shortage is already keen, emigration tends to promote inflationary pressure.

The policy best calculated to help Britain overcome the crisis is one which would welcome appropriate grades of immigrants from the continent of Europe. A high rate of immigration makes up for a low degree of internal mobility. The argument that these newcomers would be a strain on the British economy since they have to be fed and housed does not bear analysis. They are prepared to work in industries producing the most essential output-coal, textiles, food-and they are accommodated in existing premises. The value of the marginal product of immigrant labour of this kind much exceeds the cost of the imports and capital equipment needed for its employment.

Finally, there is the long-run question whether Britain can hope to sustain a population of fifty million at anything like the old standard of living when outside help is no longer available. Much will depend on the future course of the terms of trade. There are strong reasons for taking a pessimistic view. The industrializing of agricultural countries will tend to reduce exports of food from these coun. tries. A study of the stages through which the United States has passed is instructive. In poor countries like India, the peasants may sell less of their crops on the market as the price improves; they will wish to consume more themselves. Then, the principle of 'fair shares' in the allocation of food as between rich and poor nations augurs ill for the highly industrialized countries like Britain. These tendencies operating unchecked mean a continuance of dear food for the British people: whether this can be masked indefinitely by a policy of internal subsidies is questionable.

On the other hand, it may be that the world is on the eve of a great advance in the application of science to crop production. Moreover, the long-term trend in consumption habits noted in the inter-war period may yet reassert itself. The most reasonable expectation is that the terms of trade for Britain will fall somewhat from their present level, but will never again reach the favourable ratio experienced between the two World Wars. If the people respond to this stern challenge by increasing and rearranging their productive power, there is no reason why a tolerable equilibrium cannot be found for a population of fifty million. There need be no mass emigration.

In the third paper in the symposium, Mr. R. R. Rawson considered in detail the factors determining White settlement in Kenya and Rhodesia. Looking to the future, he saw signs of a more considerable White settlement in East Africa for strategic reasons; but in view of the lack of mineral resources in Kenya, such a plan would entail linking Kenya with the coal and iron deposits of Rhodesia.

The open discussion ranged widely over the ground covered by the three papers. One of the questions treated in detail was the future of the terms on which Britain can expect to purchase imported food. Reference was made to the views of authorities in other Sections of the British Association, who had pointed out that the effective supply of food could be greatly increased if the heavy loss due to destruc- tion by vermin could be partly eliminated. It was significant to observe the attention devoted to the food problem in this symposium, as in other sessions during the British Association meeting at Brighton. On the question of the White Australia policy, a representative of Section $H$ (Anthropology) disagreed with Prof. Fawcett and argued that the difficulties of assimilating coloured peoples must not be shirked. Finally, I had the feeling that Prof. Fawcett's suggestion that Australia could increase her population to $30-50$ million, and Canada to 60-100 million, was much too optimistic. A careful assessment of the probable economic trends seems to be necessary before such estimates can be put forward with any confidence.

Brinley Thomas

\section{PHYSICAL CHEMISTRY OF PROCESS METALLURGY}

$T$

HE discussion on "The Physical Chemistry of Process Metallurgy", which the Faraday Society held at Ashorne Hill, Warwickshire, during September 23-25, showed plainly that process metallurgy is now as much the province of the physical chemist as the metallurgist. Attention at this meeting was devoted almost entirely to the high-temperature processes involved in the winning and refining of metals, and here in particular it seems that advances will come mainly from the application of physical chemistry. Indeed, speaking as a steelmaker, Sir Andrew McCance (Colvilles, Ltd.) confirmed, in his introductory remarks, that the advances in the openhearth process over the past twenty years have come almost entirely from the physico-chemical approach to open-hearth reactions. In this article it is intended to touch only upon the main topics of physico-chemical interest. In so short a space it is impossible to consider all the problems discussed, and reference will not be made to those papers concerned with industrial applications.

After an opening paper by Sir Charles Goodeve (British Iron and Steel Research Association), outlining the physico-chemical principles of special importance in this field, the subject was considered in three main sections: metallic solutions; roasting and reduction processes; and slags and refining processes. In addition, a number of papers dealt with the problems associated with experimental work in the important temperature-range between $1,000^{\circ} \mathrm{C}$. and $2,000^{\circ} \mathrm{C}$. The main difficulty in handling substances at these high temperatures is finding refractory containers which will not react with them. Almost all substances become chemically reactive in such extreme conditions, since high activation energies for molecular processes are no longer seriously restrictive. Another less obvious problem, which has caused large errors in the results of many equilibrium studies between gas mixtures and metals or slags, is thermal diffusion. This is caused by the large temperature gradients which are generally unavoidable in any apparatus operating under these conditions. The heavier components in the gas mixtures used diffuse away from the hot zone, and so set up concentration differences in the apparatus which may be maintained even under steady flow conditions. These differences can be avoided by combining adequate preheating of the incoming gas with a flow-rate sufficient to prevent any significant concentration gradients from becoming established. They can also be greatly reduced, as 